(C) <2019>. This manuscript version is made available under the CC-BY-NC-ND 4.0 license http://creativecommons.org/licenses/by-nc-nd/4.0/

The definitive publisher version is available online at https://doi.org/10.1016/j.enpol.2019.05.031 


\title{
Socio-economic development and electricity access in developing economies: A Long-run model averaging approach
}

Tong Zhang ${ }^{\mathrm{a}}$, Xunpeng Shi ${ }^{\text {b,c,d }}$, Dayong Zhang ${ }^{\mathrm{e}}$ and Junji Xiao ${ }^{\mathrm{f}}$

a National School of Agricultural Institution and Development, South China Agricultural University, China

b Australia-China Relations Institute, University of Technology Sydney, Australia; Email: xunpeng.shi@uts.edu.au.

${ }^{c}$ Energy Studies Institute, National University of Singapore, Singapore

${ }^{\mathrm{d}}$ Center of Hubei Cooperative Innovation for Emissions Trading System \& School of Low Carbon Economics, Hubei University of Economics, China

${ }^{\mathrm{e}}$ Research Institute of Economics and Management, Southwestern University of Finance and Economics, China

${ }^{\mathrm{f}}$ Business School, University of Technology Sydney, Australia.

\begin{abstract}
:
Access to electricity continues to be a popular subject in empirical studies. However, the choice of key factors related to electricity access in the literature to date has been ad hoc due to the lack of a theoretical framework. This paper adopts a Bayesian Model Averaging (BMA) approach to selects important factors related to electricity access from 26 socio-economic indicators using a sample of 48 developing countries, and reveal their long-term relationship with electricity access. The BMA approach allows us to identify the optimal empirical model when a theoretical foundation is not available. Moreover, it allows us to address the relative importance of variables using posterior inclusion probabilities, and thus has clear policy relevance. Our results show that access to finance, education, economic development, infrastructure, and industrialisation are positively related to electricity access in the long-run. Although the long-run relationship does not indicate causality, it shows that to maintain this relationship, policy adjustments against any deviations from the relationship are needed. Our study suggests that electrification needs not only economic, educational and infrastructural development, but also private sector participation, governments' commitment and political will, and integration with poverty reduction and other development schemes.
\end{abstract}

Keywords: Bayesian Model Averaging; electricity access; rural electrification; social and economic development; long-run relationship; developing countries;

JEL Classification: O13, Q43, C11 


\section{Introduction}

While climate change has become a popular topic in the energy and environmental fields (Gao et al., 2019; Li et al., 2019), traditional energy issues, such as access to electricity, is still critical to the developing world. Access to electricity is a basic human right and a key precondition for eliminating poverty since it fuels the fundamental economic activities (González-Eguino, 2015). Without access to electricity, economic development is limited and modern public services, such as education and healthcare, cannot be delivered to their intended beneficiaries. A mutual relationship between the lack of access to adequate and affordable energy services and poverty is widely recognised (Sovacool and Drupady, 2012). Lack of energy access is also unanimously regarded as 'energy poverty' (Pachauri et al., 2004). There is even an argument that a lack of electricity prevents efforts to improve election quality (Penar, 2016).

Given the importance of electricity in modern energy, this paper investigates the issue of access to electricity in developing countries. Achieving universal access to electricity has increasingly become a policy focus globally. In 2015, about 1.1 billion people, the majority of whom living in rural areas, did not have access to electricity (IEA, 2017). In particular, electricity access rates are even lower among low-income people. For example, In ASEAN, despite the overall electrification rate of $91.4 \%$ in 2014, the rates of electricity access in the lower-middle-income countries of Cambodia, Lao PDR, Myanmar, the Philippines, and Timor-Leste rates ranged from only $45 \%$ to $78 \%$ (IEA, 2015).

The 2030 Agenda for Sustainable Development, adopted in 2015 by the United Nations, includes several targets, such as Sustainable Development Goal (SDG), to 
'ensure access to affordable, reliable, sustainable, and modern energy for all'. Among the Asia-Pacific countries that have yet to achieve universal access to electricity, almost all (except the Democratic People's Republic of Korea) have established an electrification target identifying goals in terms of a percentage of their population or a number of people with electricity access (ESCAP, 2017).

To formulate effective policies for the purposes of improving electricity access, there is an urgent need to understand the relationship between energy access and socio-economic development indicators. Understanding this relationship can help identify the correct policy interventions, implement appropriate monitoring mechanisms, and justify resource allocation. Revealing the complexities of the electricity-socio-economic development nexus can enhance the modelling of electricity demand and improve the projection of future electricity access and demand, its associated investment, and carbon emissions.

The selection of variables in empirical models is not straightforward. With the traditional methodology, the selection of variables is guided by theories and/or by ad $h o c$ reasons if no theory exists. However, even if there is a long-established theory, the selection of important variables is still controversial as the theory does not explicitly specify the empirical model. For example, in the case of economic growth studies, about 60 indicators, such as the initial level of income, investment rate, various measures of education, some policy indicators, etc., have been found significant in the literature (Sala-i-Martin, 1997), while no theories have accommodated all the factors in the same model. In the case of electricity access, the selection of variables is more challenging as the relationship between electricity access and socio-economic development is complex and involves many underlying forces (Riva et al., 2018). 
The existing studies on the relationship between energy access and socioeconomic development have three gaps. First, there is no theoretical foundation under this relationship giving clear instructions to empirical studies. Understanding the factors relevant to electricity access can help in the formulation of policy interventions and is useful in projecting future access to electricity, investment, and emissions. In the process of modelling and forecasting, the more important explanatory and influential variables are included, the more precise the forecast. But the problem is that no theoretical framework is available (Riva et al., 2018). Due to the lack of a theoretical foundation, the selection of indicators is random and subject to individual researchers' own interests. This can produce misleading policy implications.

Second, the existing literature on the complex relationship between electrification and the development of poor, rural communities focuses mainly on the impacts of rural electrification and electricity use on local socio-economic development. There is a dearth of studies on the impacts of the various socio-economic indicators on energy access and on the reverse relationship, that is, how social and economic changes affect electricity demand and supply (Riva et al., 2018).

Third, improving energy access requires long-term efforts, indicating that an understanding of the long-run relationship among these variables is needed. Improving access to electricity often takes time and its interaction with many socioeconomic variables is not valid in the short term. For example, one would not expect to build a grid in a matter of days; also, the impacts of modern energy access on economic development, employment, and other factors tend to last for a very long period. In this sense, long-run models are needed. 
Following the work of (Fernández et al., 2001), this paper uses the Bayesian Model Averaging (BMA) approach to identify important variables relating to electricity access. Without prior information or theory about which factors are important for electricity access, the BMA approach can find the optimal model and rank important factors using posterior inclusion probabilities.

The present work differs from the existing literature mainly in its methodological innovation and the scoped important explanatory variables. Our major contribution to the literature is the introduction of a new methodology for selecting socio-economic factors that have a long-run relationship with electricity access. The results of the study provide a reference framework for scoping policy interventions and future academic studies, such as predicting electricity access. This methodology can also be applied to similar cases to reveal an optimal model when the underlying theoretical framework is absent.

Our second contribution is identification of the long-run relationship between electricity access and socio-economic indicators. Since the relationship between electricity use and rural socio-economic development has complex feedbacks that can reinforce or balance impacts over time (Ulsrud et al., 2011), we examined the longrun correlation but not causal relations. We cannot define the causality of the factors to electricity access, but since policy-makers care about long-run impact, such an equilibrium study is appropriate. It can provide immediate value to energy policy decisions in many developing countries, including those in ASEAN. More importantly, our analysis can provide additional support to micro-level studies from the macro level, especially when the underlying theory on energy access determination is lacking. 
The paper is organised as follows: The next section reviews the literature on the long-run relationship between socio-economic indicators and electricity access and presents the data examined. Section 3 explains the methodology, followed by empirical results in Section 4. Section 5 discusses policy implications while the conclusions summarise the key findings, discusses the ideal applicability of the methodology and suggests what further work could be done.

\section{Socio-economic development and access to electricity}

Many studies have been carried out on the nexus between electricity access, including electrification, and socio-economic development. To reveal a long-run link between the two sides, this literature review is presented in two parts. Part 1 focuses on the factors that influence access to electricity, while part 2 looks at the reverse direction, that is, the impact of rural electrification on socio-economic development. Based on the availability of data at the cross-country level, we then propose the macro socio-economic indicators that are examined in this paper.

\subsection{Socio-economic factors affecting electricity access}

Many macro socio-economic factors are considered important to electricity access. An overview report by the National Renewable Energy Laboratory (date) describes the key policies that countries are using to enable the development of offgrid energy access markets with emphasis on attracting the private sector to provide energy services to rural customers. This overview addresses the government's role in each element of the market - from energy regulations to finance options and from business support to worker training (Walters et al., 2015). Magnani and Vaona (2016) found that access to energy is positively related to renewable energy generation and availability of human capital and funds. They tried to correlate electricity access (the percentage of population) to several variables, including the number of borrowers 
from commercial banks (per 1,000 adults), the percentage of total electricity produced by different sources (generate mix), GDP per capita, urbanisation rate, the percentage of GDP accruing to natural resource rents, and citizens' completion rate in lower secondary schools.

Despite the numerous studies documenting the important variables, the literature to date does not show a simple deterministic relationship between electricity access and various socio-economic development variables (Matinga and Annegarn, 2013). Cook (2011) examined some economic and social issues that underlie the development of rural electrification and found that the empirical literature reveals an inconsistent relationship between electricity access and economic growth. Ahlborg (2017) demonstrated multiple interfaces and feedback loops that shape outcomes in the electrification processes. Magnani and Vaona (2016) highlighted that the direction of econometric causality is undefined and often two-way. In a Vietnamese rural electrification case study, Khandker et al. (2013) found a circle of development among investments in other rural infrastructure services, rural electrification, educational attainment, higher income, and more investments in rural electrification.

Research on electricity access and development, including but not limited to their relationship, has been compiled in dedicated reviews, such as Riva et al. (2018) and Attigah and Mayer-Tasch (2013). Khennas (2012) argued that in building energy infrastructure (power plants, grid interconnections, and small-scale decentralised energy options in rural areas), a long-term energy strategy and large-scale programme are preconditions for economic growth, and ultimately, for energy access. Cook (2011) found that industrialisation has been increasingly considered a key approach to increase rural income, and electrification is an enabling factor in industrialisation. 
Many studies show that access to finance is a key factor in the success of electrification projects. Rural electrification, particularly through off-grid renewable projects, often faces financial challenges such as high initial costs, limited local financial resources, low return rates, and 'unaffordability', i.e., the existing lending terms set by lenders (or funders) are often unsuitable for Off Grid Renewable Energy projects (Ji and Zhang, 2019; Shi et al., 2016). Well-designed policies, appropriate institutional arrangements, and effective financing mechanisms are necessary to enable the successful and sustainable deployment of electrification projects (Deshmukh et al., 2013). Shi et al. (2016) quantitatively assessed support instruments for off-grid renewable electricity access projects and identified the important instruments in achieving feasible, sustainable, and replicable (a holistic assessment framework) electricity access projects. Supporting instruments that have been examined include financial incentives (e.g. soft loans, grants, publicly backed guarantees), fiscal incentives (e.g. exemption of import duty, value added tax), and elimination of market distortions (e.g. reducing fossil fuel subsidies). Magnani and Vaona 2016) considered the number of borrowers from commercial banks (per 1,000 adults) as a measure of access to funds.

Although it is difficult to measure the relations between natural factors and electricity access (Dinkelman, 2011), used land gradient as an exogenous variable representing the challenge, and thus the cost of connecting households. Using distance from the village to the district capital, Oda and Tsujita (2011) showed that location is a key factor in electricity access as governments tend to pick the easily achievable task first in the rural electrification process. Magnani and Vaona (2016) found that the share of rents from natural resources to GDP is positively related to providing 
electricity access and hence use the completion rate in lower secondary schools to measure human capital.

A few case studies also demonstrate the relevant factors for successful rural electrification. In the case of Bangladesh, a study (Rahman et al., 2013) found that the key driving factors behind electrification are prioritising system investment, community involvement, anti-corruption features, standardised practices and performance-based incentives while excluding political parties. With respect to some villages in India, Kemmler (2007) found that household characteristics, the degree of community electrification, and the quality of electricity supply play important roles in determining household electrification. Household expenditure and the electricity tariff had only small effects on a household's choice for electricity.

Table 1 summarises the factors affecting electricity access that have been discussed in the review.

(Insert Table 1 here)

\subsection{Impact of rural electrification on socio-economic development}

As there are numerous studies on the impacts of rural electrification on households and communities, this review is not intended to be comprehensive. Instead, we highlight only some of the typical issues and controversies.

Typical impact issues include education, health, income, and labour supply. Javadi et al. (2013) found that rural electrification has a positive impact on education and health. Dinkelman (2011) found that rural electrification increases employment by releasing women from household chores and facilitating microenterprises. However, it reduced female wages and increased male wages. A World Bank comprehensive review on the methodology measuring the socio-economic benefits of rural electrification on local communities in low-income countries concluded that 
electrification can positively impact the growth of local income-generating activities, time savings, and educational and health improvements. (World Bank, 2008).

Khandker et al. (2014) found that rural electrification increases children's study time, the labour supply, schooling, and household per capita income and expenditure. A study on the welfare impacts of rural electrification in Vietnam found that electrification has significant positive impacts on households' cash income, expenditure, and educational outcomes (Khandker et al., 2013).

The impact assessment of rural electrification goes beyond these typical issues. A case study of South Korean electrification demonstrated that rural electrification does not benefit the poorest quartile of rural households. Rather it has a few negative impacts such as increased economic and social inequality, household debt, and accelerated migration to urban areas (van Gevelt, 2014). Kanagawa and Nakata (2008) found that quality of life, GDP, education, and poverty are closely related to access to modern energy and that the literacy rate is affected by the household electrification rate, the $1,000 \mathrm{~km}^{2}$ road density, and sex ratio. A case study of the Philippines found that rural electrification contributes to cheaper and greater use of lighting, radio and television; improves returns on education, wage income, and productivity of home business; and saves time in housework (World Bank, 2002).

The impacts of rural electrification on socio-economic development, however, are inconclusive. A review of the literature on the relationship between electricity access and its impacts on rural socio-economic development from case studies (Riva et al., 2018) confirmed that access to electricity has complex causal relations with various socio-economic indicators, which are broadly categorised as incomegenerating activities, market production and revenues, household economy, local health and population, education, and habits and social networks. Using survey data 
from various countries in sub-Saharan African countries, Peters and Sievert (2016) showed that rural electrification has no impact on health, children's study time, and income. The considerable studies on the impacts of rural electrification on various outcomes found that the impacts vary by region and that those in Asia are more positive than those in Africa (Saing, 2018).

The impacts could be gender biased. The study panel data in 1982 and 1999 from India, (van de Walle et al., 2017) found a positive, but smaller, long-term impact on household consumption and a positive impact on schooling for girls but not for boys. The gender asymmetric impact is different in Cambodia. A recent Cambodian case study found that rural electrification increased household consumption by approximately $16.6 \%$, increased years of completed schooling by 0.85 for boys and 0.62 for girls. It also found that electrification increased the probability of primary school enrolment for boys by about $9.7 \%$ but had no impact on girls' school enrolment (Saing, 2018).

The impacts are dependent on the time horizon. Aragaw (2013) found that the impacts of rural electrification depend on the number of years that a household has an electricity connection. The immediate benefits include improved quality of life through better lighting and reduced indoor air pollution. The gradual impacts include diversified income and improved public services such as education, health, and potable water, as well as wider off-farm and non-farm employment, increased rural markets, and improved environment for rural development.

(Insert Table 2 here) 


\subsection{Selected indicators for this study}

A review of possible macro socio-economic factors that are either important in, or are impacted by, access to electricity, are available in the World Bank World Development Indicators. We selected 26 potential influential factors of electricity access for 48 developing and low-income countries. The sample selection in our empirical analysis was restricted by the availability of data. Generally speaking, the objective was to keep as many variables as possible while keeping the most relevant countries. Developed economies were excluded in our analysis given that they had long ago achieved $100 \%$ electrification, thus, making them irrelevant for the purposes of this study.

As typically found in the existing literature, the related economic factors include current account balance, manufacturing share of GDP, exports, inflation, and GDP per capita. The financial variables include number of bank branches, domestic credit to the private sector, and interest rates (lending and real interest rates). The commercial bank branches indicate the availability of financing institutes while the domestic credits to the private sector not only measure access to finance but also its magnitude. Four infrastructure variables - electricity transmission and distribution loss, time required to get electricity, mobile phone and fixed line subscriptions, and individuals using the Internet - were included. The social indictors include the number of employers, unemployment rate, net official development assistance received per capita, school enrolment, and urbanisation.

The natural factors include percentage of arable land, population density, energy efficiency, and the energy imports situation. The higher the proportion of arable land, the lower the challenge it is to provide electricity; and the higher the population density, the more cost-effective it is to provide electricity access. 
We also include fiscal status, which indicates the available financial resources of the government. We opted to do this because our study is a national-level study. Since the government is often the primary responsible stakeholder of electrification, the more resources the government owns, the better opportunities to increase electricity access. The current account balance, general government final consumption expenditure, external debt stocks, and foreign direct investment are all possible variables that can be used to measure the fiscal acceptability of governments.

In each category, we may have had similar indictors. The variables and their definitions are presented in Table 3.

(Insert Table 3 here)

The data used in the BMA framework is the 10-year average of each variable, which is similar to Sala-i-Martin (1997) who investigated the determinants of longrun economic growth. Causality is often hard to address in macroeconomic models, as the economy is essentially a system, which means all variables should be considered endogenous (Sims, 1980). Moreover, in many cases, it is often more relevant to look at the long-term relationship rather than the short-run dynamics. For example, the long-run equilibrium correction model introduced by Engle and Granger (1987) has been widely used to address macroeconomic problems. Under such logic, once a longrun equilibrium relationship is established, any short-term deviation will adjust back to that relationship.

The descriptive statistics are given in Table 3. Although the sample countries are all from the developing world, there are still quite significant variations in their access to electricity. The lowest number was $12.53 \%$ (Tanzania) and the highest was $99.93 \%$ (Lebanon). In terms of electricity consumption per capita, Tanzania remained the lowest country whereas South Africa was the highest. The difference here may simply 
reflect that accessibility and affordability may be different issues among different countries.

\section{Methodology: Bayesian model averaging (BMA)}

Specifying an empirical model for regression analysis is often challenging especially when an underlying economic theory is not available. With many possible factors available, a particular subset of factors is normally used (Sala-i-Martin, 1997), which can lead to ambiguous conclusions due to sampling, model selection, and shortrun variations in the system, leading to unclear policy instructions.

Leamer $(1985,1983)$ initiated a discussion on this issue, and was followed by Sala-i-Martin (1997) and others. The discussions lead to the concept of model selection techniques, which have been used widely in the literature. For example, Dong et al. (2011) used Extreme Bound Analysis (EBA) to identify the determinants of outward investment from China and the US. Zhang et al. (2016) used the Bayesian averaging approach to study the determinants of energy intensity in China. MoralBenito (2015) provided a survey of literature in economics that use model-averaging technics.

The basic philosophy of model selection is to let the data identify the scenario when an underlying theory does not apply. All possible combinations of variables should be considered, which result in a total number of $2^{K}(K$ is the number of variables) models. Then an optimal model can be identified. The importance of each variable can be extracted from its marginal contributions.

When $K$ is large, the total number of models will be too large to be estimated at all. The BMA approach, introduced by Hoeting et al. ( 1999), can be used to solve this problem. Fernández et al. (2001) provided a practical guide of the model and their R package is used in this paper to rank the relative importance of variables. 
Here we provide a very brief introduction to the model. Suppose $Y$ is a dependent variable for $n$ countries, and there are $K$ possible explanatory variables in the matrix $\mathrm{Z}$, which is a $(\mathrm{n} \times \mathrm{K})$ matrix. Levine and Renelt (1992) assumed a subset of models with fixed size to be evaluated for identifying the optimal model. The BMA approach, however, allows all possible combinations to appear, and thus results in a total number of $2^{K}$ models. Denote $M_{j}$ is the model with the $j^{\text {th }}$ group regressors $\left(Z_{j}\right)$, then the model specification is given by,

$$
\mathrm{Y}=\alpha_{j}+\beta_{j} Z_{j}+\varepsilon_{j}
$$

The prior distribution of model $M_{j}$ is specified as:

$$
P\left(M_{j}\right)=p_{j}, \quad j=1, \ldots, 2^{K}
$$

A uniform distribution is normally used for the prior distribution such as $p_{j}=$ $2^{-K}$, which gives each model the same prior probability. Fernandez et al. (2001) show how to calculate the marginal likelihood of model $M_{j}$ as $l\left(M_{j}\right)$, and then use this marginal likelihood to calculate the posterior model probabilities:

$$
P\left(M_{j} \mid Y\right)=\frac{l\left(M_{j}\right) p_{j}}{\sum_{h=1}^{2^{K}} l\left(M_{h}\right) p_{h}}
$$

The general idea of this procedure is that models with higher marginal likelihood should have higher probability to be included. $P\left(M_{j} \mid Y\right)$ will then be used to identify posterior distribution of parameters or the predictive probabilities. The problem with this procedure is that it is impossible to calculate all posterior probabilities of $2^{K}$ models, even when $K$ is in a moderate size, such as larger than 25 (George and McCulloch, 1997). To solve this computational problem, the Markov Chain Monte Carlo Model Composition $\left(M C^{3}\right)$ sampler (Madigan et al., 1995) can be applied. 
The original data is in annual frequency from 2005 to 2014 (10 years). The regression analysis was done on 48 countries from the low- and lower-income category. The main variable of interest (Y) is access to electricity.

\section{Empirical results}

Table 4 shows the BMA model selection results for influencing factors in access to electricity. The table reports posterior inclusion probability, posterior mean, posterior standard deviation (SD) and also percentage of conditional positive sign (as in Sala-i-Martin, 1997). The variables are ranked according to the posterior inclusion probabilities.

(Insert Table 4 here)

It is worth mentioning again that the number of possible models $\left(2^{26}\right)$ is very large. To exhaust all possible combinations, we needed to run a total of 67.1 million regressions. With $M C^{3}$, the final number of models used was 66,593 and it was substantially smaller. The optimal model size was 4.4634 , meaning that the most important factors were between 4 and 5. Table 4 also reports the conditional posterior mean and standard deviation for each variable in the regressions (on the condition that the variable is included in the model).

(Insert Figure 1 here) 
Figure 1 shows graphically the cumulative model probabilities, conveying similar information using the best 2,000 models. It is visually clear that 'bank' was the most influential factor and was included in most of the regressions.

Figure 2 plots the model size. The red line is prior model size; given uniform distribution, the expected model size was 13 with a probability equal to $c(26,13) \times$ $2^{-26}=15.5 \%^{1}$, where the posterior model size was expected to be 4.4634 , putting more importance on a parsimonious model.

(Insert Figure 2 here)

Assuming all variables have equal probability to enter the optimal model, the prior inclusion probability is therefore $22.4 \%(1 / 4.4634)$, which can be used as a threshold to select important variables (separated by the dashed line). Among all six (ranked according to their posterior inclusion probability, PIP) most important factors, Bank represents a country's financial development and, thus, better financial development is positively associated with access to electricity. Establishing electricity infrastructure requires a major investment that is not accessible by the private equity market. A country with a powerful banking system tends to be able to mobilise more capital engaging in the improvement of electricity access, which is consequentially beneficial for market development. The expected relationship of 'bank' and access to electricity is positive. Figure 3(a) plots the marginal density of the estimation of 'bank'. It has the largest PIP (included in $58.89 \%$ of all models), and its conditional

\footnotetext{
${ }^{1} \mathrm{C}(\mathrm{n}, \mathrm{k})$ is the mathematical notation for k-combination of a set $\mathrm{S}$ with $\mathrm{n}$ elements. The formula is $\mathrm{C}(n, k)=\left(\begin{array}{l}n \\ k\end{array}\right)=\frac{n !}{k !(n-k) !}$, where ! represents factorials.
} 
posterior mean coefficient is 10.59 . Two standard deviation bounds w/were all positive (satisfying the extreme bound set up (Leamer, 1983), meaning, this variable's relationship with access to electricity is robust and not sensitive to the choice of models.

(Insert Figure 3 here)

Two other economic variables, GDP per capita and share of the manufacturing industry, ranked second and fourth, and were both positively related to access to electricity. The causality among these variables may be bi-directional but they are positively related. A simple argument would be that a country with higher income would improve electricity access in the long run. Whereas more electricity access can also boost its economic potential and, thus, increase income levels. Certainly, the increased access to electricity will boost manufacturing industrial development, which, in turn, will increase electricity access by developing the economy. The marginal density for GDP per capita is plotted in Figure 3(b). Its PIP is $45.46 \%$ with conditional mean equals 14.42

Figure 3(c) is the manufacturing share (ranked number 4) with a PIP of $41.85 \%$. School is the second most important variable. It is easy to understand that access to electricity can help improve the educational status of a country (positive relationship). Meanwhile, better education can benefit a country's development, which also increases the possibility of more electricity access. The positive relationship of the educational factor is consistent with the assumption in the limited literature, such as 
(Khennas, 2012), in which the school variable was explained as a proxy of human capital. School has a PIP of 42.22\%, which is plotted in Figure 3(d).

The last two important variables are internet and tele. They are only marginally included in the long-run relationship as the expected model size is 4.4634 . Nonetheless, their positive relationship (see Figure 3(e)) with access to electricity is not entirely surprising since they are all related to infrastructure development. This is also consistent with literature such as Khandker et al. (2013) and Khennas (2012).

In contrast to the existing literature, we found that urbanisation does not facilitate increasing energy access. It is widely assumed that in the electricity access literature urbanisation is the driving factor behind improvement in electricity access. For example, the Economic and Social Commission for Asia and the Pacific (ESCAP) (2017) reported that urbanisation has facilitated the growth in overall and rural electrification rates in some areas. This is shifting the distribution of populations and affecting electrification rates across the sub-regions of East and Northeast Asia, South and Southwest Asia, and Southeast Asia.

According to our estimation, the expected relationship between urbanisation and access to electricity is unclear and subject to the choice of models. Figure 3(f), for example, plots its marginal density. First, it has a very low PIP (5.41\%), meaning that it contributes much less than the above variables to the variation in access to electricity. Second, the conditional mean of urban is negative, and its two standard deviation bounds are located on both sides of zero, which means the relationship can be positive or negative, and is sensitive to the choice of models. Therefore, we cannot justify a long-run relationship between urbanisation and access to electricity here. This discrepancy is likely because urbanisation and electrification have different dynamics and are therefore not related when other factors are controlled. 
While the natural factor influences electrification, in the long run, there is no significant relationship between landscape (approximated by percentage of arable land) and population density. This suggests that unfavourable natural conditions are not long-run barriers for increasing electricity access. This can be seen in China's achievement of universal access to electricity despite the presence of numerous challenging landscapes such as mountains and deserts.

The impact of the labour market is also not important. This is likely due to the country level aggregated data. In the village level, unemployment is expected to be related to electricity access and labour. Female workers are particularly likely to be freed from household work (Khandker et al., 2014). There is also evidence that rural electrification facilitates the development of microenterprises (Dinkelman, 2011). However, this impact may be limited at the aggregate level as the marginal impact of rural electrification is negligible at the national level.

\section{Discussion}

While the majority of the existing studies aim to find a causal relationship between electrification and other socio-economic factors, in the hopes of deriving direct policy implications, the findings are often controversial. Compared to most of the previous work done on this topic, by focusing on long-run relations, not causality, our empirical results offer a different perspective on the nexus between electricity access and socio-economic development. Based on the results, we propose the following policy implications for policy-makers in developing countries, including ASEAN countries.

First, policy-makers should aim to improve economic conditions so as to increase access to electricity. Energy-growth nexus is perhaps the most investigated issue in the literature and the link is well established (i.e. Zhang (2008) and Shi and Sun 
(2017)). A stronger economic growth will provide the country resources for improving electricity access. Poor economic development is generally associated with a lower electrification rate. It is unlikely that a country can improve electricity without improving its general economic conditions. Without economic support in the first place, any attempt to improve access to electricity lacks a foundation. Of course, the positive relationship also indicates that improving electricity access can contribute to economic development.

Second, policy-makers should make the development of the financial sector a priority. Developing countries, especially those with low per capita incomes, tend to have a more inferior financial system, which is the most important factor linked to electricity access. Ji and Zhang (2019), for example, shows that financial development is one of the most important factor to the development of renewable energy sector in China, whereas renewable energy development is an important alternative to achieve sustainable energy access, especially to the poor and less developed areas. Financing requirements of electricity projects are less likely to be satisfied in a country with low financial development. Prioritization of the development of the financial sector is consistent with the general idea of building an 'inclusive financial system' proposed by the United Nations (UNCDF, 2005). Making financial services available and allowing people to fully participate in the financial sector are significant. A welldeveloped and healthy financial sector is not only able to provide financing opportunities to electrification projects; it also allows poor people to be able to afford the use of modern energy.

Third, the long-run benefits associated with increased schooling must be taken into account when a government decides to provide electricity access. Education is a factor that found to have bidirectional causal relationship with energy access in the 
short-run (Alam et al., 2018). We also show here educational investment can also have long-run impacts on rural electrification. A previous study has found that lack of local operation and maintenance due to insufficient local expertise is a key challenge to rural electrification projects (Shi et al., 2016). Rural areas without electricity are also often poor in terms of education. Improving access to electricity can increase schooling, which in turn can lead to human capital development and help to maitian the electrification project. The electrification will also raise the wealth of households, and therefore the access to electricity in the long run.

Fourth, rural electrification should be integrated into wider rural development schemes, such as industrialisation and poverty reduction, making the access to electricity projects sustainable. The long-run linkage between industrialisation and electricity access justifies the interconnection of the two factors. Industrialisation will increase a community's electricity demand and thus reduce the unit cost of providing electricity assess. In the absence of industrial demand, providing access to a rural community, cost per unit of electricity consumed may be prohibitive (Shi et al., 2016). Moreover, industrialisation will generate additional income for a community, thus reducing poverty and increasing the citizens' ability to pay for electricity. Given the observation economic development will shift manufacturing from more developed countries to less developed countries (Liu et al., 2018), economic development will advance electricity by creating sustainable and affordable electricity demand and reduce average cost.

Lastly, rural electrification requires strong government commitment and political will to invest in public services and infrastructure. The two factors that have positive long-run links with rural electrification - schooling and infrastructure development are public services and therefore need government investment. Resolving energy 
poverty and achieve wider access to modern energy requires more government involvements (Rains and Abraham, 2018). Our finding that fiscal status does not have a long-run relationship with access to electricity suggests that a government could advance rural electrification even under fiscal constraints. This is possible due to private sector investment. The private sector may play a pivotal role in closing the investment gap and in innovating new technologies, delivery methods, and business models. Many earlier studies have demonstrated that the willingness to pay for electricity is higher than the long-run marginal cost of supply. Thus, rural electrification investments can be financially sustainable (World Bank, 2008). Private sector entities have been relatively long-term proponents and actors in rural electrification for a small number of Asia-Pacific countries, such as India, Indonesia, and the Lao People's Democratic Republic (ESCAP, 2017). Private sector participation requires the government to set a proper and stable policy framework (Shi et al., 2016).

\section{Conclusions and policy implications}

Lack of electricity access is a major challenge for the social and economic development of developing countries. Providing universal access to clean energy, mainly electricity, has gained global momentum and many governments are committed to improving electricity access. However, there is no underlying theory to guide policy interventions. The current practice of arbitrarily choosing a particular subset of variables can lead to ambiguous conclusions and consequently unclear policy implications.

In this paper, we used Bayesian Model Averaging (BMA) techniques to identify important variables for electricity access at the national level. We examined long-run - not causal - relationships to avoid the controversies of complex causality between 
electricity access and socio-economic development. This method could justify the selection of variables for future econometric studies and could be applied to regionaland even community-level studies.

We found that six factors--financial development (bank), income ( $p g d p)$, education (school), industrial structure (manu), infrastructure development (internet and tele), have a long-run relationship with electricity access. In contrast, some frequently mentioned factors, such as urbanisation, natural landscape, and government fiscal conditions, are not influencing factors. The long-run stable relationship between electricity access and the six influencing factors could well predict the electrification access rate in the sample. This finding suggests that, in those previous econometric studies without economic theory as the foundation, the BMA approach can be used to assist their model specification process to generate robust results.

From a policy perspective, this study suggests that governments need to pay more attention to the most important factors found for achieving long-term solution to electrification. Briefly speaking, governments should: improve economic conditions; prioritize to the development of financial sector and provide more convenient access to finance; provide better education; integrate rural electrification into wider rural development schemes to allow synergize among various initiatives; and firm strong government commitment and political will to invest in public services and infrastructure and support private sector participation.

Our data-driving methodology, although increasing in popularity, does, however, lack a theoretical framework and therefore the methodology should be limited to cases which do not have an underlying theory to guide variable selection. For future studies, several potential issues should be noted. First, the methodology could be applied to a sub-region or even at the community level where the socio-economic indicators are, 
unlike the situation with the national data, less likely to be affected by other factors.

Second, while this paper focuses on the long-run relationship, it would be interesting

to explore short-run issues because this is the way towards long-run equilibrium.

Acknowledgements: We thank the financial support from the Economic Research Institute for ASEAN and East Asia's FY2017-2018 Study on 'Energy Poverty in the ASEAN Region' and valuable comments from Prof Fukunari Kimura, Dr Phoumin Han, and other participants in the project's two working group meetings. Tong gratefully acknowledges the financial support of the Planning Projects of Humanities and Social Sciences Foundation of Ministry of Education of China (No. 15XJA790006). Xunpeng likewise acknowledges the financial support of the National Natural Science Foundation of China under Grant Nos. 71828401 and 71873029, as does Dayong for the financial support from the National Natural Science Foundation of China under Grant No. 71573214 and the 111 Project under Grant No. B16040.

\section{References}

Ahlborg, H., 2017. Towards a conceptualization of power in energy transitions. Environ. Innov. Soc. Transitions 25, 122-141. https://doi.org/10.1016/j.eist.2017.01.004

Alam, M.S., Miah, M.D., Hammoudeh, S., Tiwari, A.K., 2018. The nexus between access to electricity and labour productivity in developing countries. Energy Policy. https://doi.org/10.1016/j.enpol.2018.08.009

Aragaw, M.L., 2013. Assessing the impacts of rural electrification in Sub-Saharan Africa: The case of Ethiopia. Diss. Abstr. Int. Sect. B Sci. Eng.

Attigah, B., Mayer-Tasch, L., 2013. The impact of electricity access on economic development: A literature review, in: Mayer-Tasch, L., Mukherjee, M., Reiche, K. (Eds.), Productive Use of Energy. (PRODUSE): Measuring Impacts of Electrification on Micro-Enterprises in Sub-Saharan Africa. Eschborn, Germany: GIZ.

Cook, P., 2011. Infrastructure, rural electrification and development. Energy Sustain. Dev. 15, 304-313. https://doi.org/10.1016/j.esd.2011.07.008

Deshmukh, R., Carvallo, J.P., Gambhir, A., 2013. Sustainable Development of Renewable Energy Mini-grids for Energy Access: A Framework for Policy Design. Lawrence Berkeley National Laboratory, Berkeley.

Dinkelman, T., 2011. The Effects of Rural Electrification on Employment: New Evidence from South Africa. Am. Econ. Rev. 101, 3078-3108. https://doi.org/10.1257/aer.101.7.3078

Engle, R.F., Granger, C.W.J., 1987. Co-Integration and Error Correction: Representation, Estimation, and Testing. Econometrica 55, 251. https://doi.org/10.2307/1913236

ESCAP, 2017. Global Tracking Framework 2017: Asia-Pacific Progress in Sustainable Energy. ESCAP, Bangkok.

Fernández, C., Ley, E., Steel, M.F.J., 2001. Model uncertainty in cross-country growth regressions. J. Appl. Econom. 16, 563-576. https://doi.org/10.1002/jae.623 
Gao, G., Chen, M., Wang, J., Yang, K., Xian, Y., Shi, X., Wang, K., 2019. Sufficient or insufficient: Assessment of the intended nationally determined contributions ( INDCs ) of the world' s major greenhouse gas emitters. Front. Eng. Manag. 119. https://doi.org/http://journal.hep.com.cn/fem/EN/10.1007/s42524-019-0007-6

George, E.I., McCulloch, R.E., 1997. Approaches for Bayesian variable selection. Stat. Sin. 7, 339-374.

González-Eguino, M., 2015. Energy poverty: An overview. Renew. Sustain. Energy Rev. 47, 377-385. https://doi.org/10.1016/j.rser.2015.03.013

Hoeting, J., Madigan, D., Raftery, A., Volinsky, C., 1999. Bayesian model averaging. Stat. Sci. 14, 382-401. https://doi.org/10.1002/9781118445112.stat07874

IEA, 2017. World Energy Outlook 2017. OECD Publishing, Paris.

IEA, 2015. World Energy Outlook (WEO) 2015 Energy Access Database.

Javadi, F.S., Rismanchi, B., Sarraf, M., Afshar, O., Saidur, R., Ping, H.W., Rahim, N.A., 2013. Global policy of rural electrification. Renew. Sustain. Energy Rev. https://doi.org/10.1016/j.rser.2012.11.053

Ji, Q., Zhang, D., 2019. How much does financial development contribute to renewable energy growth and upgrading of energy structure in China? Energy Policy 128.

Kanagawa, M., Nakata, T., 2008. Assessment of access to electricity and the socioeconomic impacts in rural areas of developing countries. Energy Policy 36, 20162029. https://doi.org/10.1016/j.enpol.2008.01.041

Kemmler, A., 2007. Factors influencing household access to electricity in India. Energy Sustain. Dev. 11, 13-20. https://doi.org/10.1016/S0973-0826(08)60405-6

Khandker, S.R., Barnes, D.F., Samad, H.A., 2013. Welfare Impacts of Rural Electrification: A Panel Data Analysis from Vietnam. Econ. Dev. Cult. Change 61, 659-692. https://doi.org/10.1086/669262

Khandker, S.R., Samad, H.A., Ali, R., Barnes, D.F., 2014. Who benefits most from rural electrification? Evidence in India. Energy J. 35, 75-96. https://doi.org/10.5547/01956574.35.2.4

Khennas, S., 2012. Understanding the political economy and key drivers of energy access in addressing national energy access priorities and policies: African Perspective. Energy Policy 47, 21-26. https://doi.org/10.1016/j.enpol.2012.04.003

Leamer, E.E., 1985. Sensitivity analyses would help. Am. Econ. Rev. https://doi.org/10.1126/science.151.3712.867-a

Leamer, E.E., 1983. Let's take the con out of econometrics. Am. Econ. Rev. 73, 31-43. https://doi.org/10.2307/1803924

Levine, R., Renelt, D., 1992. A Sensitivity Analysis of Cross Country Growth Regressions. Am. Econ. Rev. 82, 942-963. https://doi.org/10.2307/2117352

Li, Z., Shao, S., Shi, X., Sun, Y., Zhang, X., 2019. Structural transformation of manufacturing, natural resource dependence, and carbon emissions reduction: Evidence of a threshold effect from China. J. Clean. Prod. https://doi.org/10.1016/j.jclepro.2018.09.241

Liu, Y., Shi, X., Laurenceson, J., 2018. Are China's Exports Crowding Out or Being Crowded Out? Evidence from Japan's Imports. China World Econ. 26, 1-23. https://doi.org/10.1111/cwe.12246

Madigan, D., York, J., Allard, D., 1995. Bayesian graphical models for discrete data. Int. Stat. Rev. 63, 215-232. https://doi.org/10.2307/1403615

Magnani, N., Vaona, A., 2016. Access to electricity and socio-economic characteristics: Panel data evidence at the country level. Energy 103, 447-455. https://doi.org/10.1016/j.energy.2016.02.106 
Matinga, M.N., Annegarn, H.J., 2013. Paradoxical impacts of electricity on life in a rural South African village. Energy Policy 58, 295-302. https://doi.org/10.1016/j.enpol.2013.03.016

Oda, H., Tsujita, Y., 2011. The determinants of rural electrification: The case of Bihar, India. Energy Policy 39, 3086-3095. https://doi.org/10.1016/j.enpol.2011.02.014

Pachauri, S., Mueller, A., Kemmler, A., Spreng, D., 2004. On measuring energy poverty in Indian households. World Dev. 32, 2083-2104. https://doi.org/10.1016/j.worlddev.2004.08.005

Penar, P., 2016. What lies behind Africa's lack of access and unreliable power supplies [WWW Document]. Conversat. URL https://theconversation.com/what-liesbehind-africas-lack-of-access-and-unreliable-power-supplies-56521

Peters, J., Sievert, M., 2016. Impacts of rural electrification revisited - the African context. J. Dev. Eff. 8, 327-345. https://doi.org/10.1080/19439342.2016.1178320

Rahman, M.M., Paatero, J. V., Poudyal, A., Lahdelma, R., 2013. Driving and hindering factors for rural electrification in developing countries: Lessons from Bangladesh. Energy Policy 61, 840-851. https://doi.org/10.1016/j.enpol.2013.06.100

Rains, E., Abraham, R.J., 2018. Rethinking barriers to electrification: Does government collection failure stunt public service provision? Energy Policy. https://doi.org/10.1016/j.enpol.2017.12.011

Riva, F., Ahlborg, H., Hartvigsson, E., Pachauri, S., Colombo, E., 2018. Electricity access and rural development: Review of complex socio-economic dynamics and causal diagrams for more appropriate energy modelling. Energy Sustain. Dev. 43, 203-223. https://doi.org/10.1016/j.esd.2018.02.003

Saing, C.H., 2018. Rural electrification in Cambodia: does it improve the welfare of households? Oxford Dev. Stud. 46, 147-163. https://doi.org/10.1080/13600818.2017.1340443

Sala-i-Martin, X.X., 1997. I Just Ran Two Million Regressions. Am. Econ. Rev. https://doi.org/10.1126/science.151.3712.867-a

Shi, X., 2016. The future of ASEAN energy mix: A SWOT analysis. Renew. Sustain. Energy Rev. 53, 672-680. https://doi.org/10.1016/j.rser.2015.09.010

Shi, X., Liu, X., Yao, L., 2016. Assessment of instruments in facilitating investment in off-grid renewable energy projects. Energy Policy 95, 437-446. https://doi.org/10.1016/j.enpol.2016.02.001

Shi, X., Sun, S., 2017. Energy price, regulatory price distortion and economic growth: A case study of China. Energy Econ. https://doi.org/10.1016/j.eneco.2017.02.006

Sims, C.A., 1980. Macroeconomics and Reality. Econometrica 48, 1. https://doi.org/10.2307/1912017

Sovacool, B.K., Drupady, I.M., 2012. Energy access, poverty, and development: The Governance of Small-scale Renewable Energy in Developing Asia. Ashgate, cop., Farnham.

Ulsrud, K., Winther, T., Palit, D., Rohracher, H., Sandgren, J., 2011. The Solar Transitions research on solar mini-grids in India: Learning from local cases of innovative socio-technical systems. Energy Sustain. Dev. 15, 293-303. https://doi.org/10.1016/j.esd.2011.06.004

UNCDF, 2005. Microfinance and the Millennium Development Goals: A reader's guide to the Millennium Project Reports and other UN documents, International Year of Microcredit 2005. International Year of Microcredit.

van de Walle, D., Ravallion, M., Mendiratta, V., Koolwal, G., 2017. Long-term gains from electrification in rural India. World Bank Econ. Rev. 31, 385-411. https://doi.org/10.1093/wber/lhv057 
van Gevelt, T., 2014. Rural electrification and development in South Korea. Energy Sustain. Dev. 23, 179-187. https://doi.org/10.1016/j.esd.2014.09.004

Walters, T., Esterly, S., Cox, S., Reber, T., Rai, N., 2015. Policies to Spur Energy Access: Volume 1: Engaging the Private Sector in Expanding Access to Electricity. Golden, CO.

World Bank, 2018. World Development Indicators. The World Bank, Washingtong, D.C.

World Bank, 2008. The Welfare Impact of Rural Electrification: A Reassessment of the Costs and Benefits, International Finance. The World Bank, Washington, D.C. https://doi.org/978-0-8213-7368-2

World Bank, 2002. Rural Electrification and Development in the Philippines: Measuring the Social and Economic Benefits, UNDP/Energy Sector Management Assistance Program (ESMAP) Report No. 255/02. Washington D.C.

Zhang, D., 2008. Oil shock and economic growth in Japan: A nonlinear approach. Energy Econ. 30 , 2374-2390. https://doi.org/http://dx.doi.org/10.1016/j.eneco.2008.01.006 
Tables and figures

Table 1. Socio-economic factors affecting access to electricity in the literature

\begin{tabular}{|c|c|}
\hline Category & Indicator (article) \\
\hline $\begin{array}{l}\text { Economic } \\
\text { factors }\end{array}$ & $\begin{array}{l}\text { Household income/expenditure (Cook, 2011; Kemmler, 2007; Shi et } \\
\text { al., 2016); economic growth/ higher income (Cook, 2011; Khandker } \\
\text { et al., 2013); industrialisation (Cook, 2011); GDP per capita, } \\
\text { urbanisation rate, the percentage of GDP accruing to natural resource } \\
\text { rents (Magnani and Vaona, 2016); }\end{array}$ \\
\hline Energy & $\begin{array}{l}\text { Tariff and subsidy policies (Cook, 2011; Kemmler, 2007); Energy } \\
\text { infrastructure, long-term energy strategy, and large-scale programme } \\
\text { (Khennas, 2012); community electrification rate, quality of electricity } \\
\text { supply (Kemmler, 2007); generation mix (Magnani and Vaona, 2016); }\end{array}$ \\
\hline $\begin{array}{l}\text { Financial } \\
\text { services and } \\
\text { support }\end{array}$ & $\begin{array}{l}\text { Effective financing mechanisms (Deshmukh et al., 2013); Number of } \\
\text { borrowers from commercial banks (per 1,000 adults) (Magnani and } \\
\text { Vaona, 2016); Access to finance (Shi et al., 2016); loan guarantees, } \\
\text { start-up grants, end-user financing, concessional finance (Shi et al., } \\
\text { 2016); Catalysing finance and financial support (Walters et al., 2015); }\end{array}$ \\
\hline $\begin{array}{l}\text { Nature and } \\
\text { infrastructure }\end{array}$ & $\begin{array}{l}\text { land gradient (Dinkelman, 2011); Infrastructure (Cook, 2011); } \\
\text { Investments in other rural infrastructure services (Khandker et al., } \\
\text { 2013); Location (distant from district capital) (Oda and Tsujita, 2011); } \\
\text { Prioritising system investment (Rahman et al., 2013); }\end{array}$ \\
\hline $\begin{array}{l}\text { Institution } \\
\text { and policy }\end{array}$ & $\begin{array}{l}\text { Well-designed policies, appropriate institutional arrangements } \\
\text { (Deshmukh et al., 2013); anti-corruption features (Rahman et al., } \\
\text { 2013); standardised practices and performance-based incentives } \\
\text { while excluding political parties (Rahman et al., 2013); Enabling policy } \\
\text { environment, integrating with development programmes (Walters et } \\
\text { al., 2015); }\end{array}$ \\
\hline Social factor & $\begin{array}{l}\text { Inequality (Cook, 2011); educational attainment (Magnani and Vaona, } \\
\text { 2016; Khandker et al., 2013); Household characteristics (Kemmler, } \\
\text { 2007); local/community involvement/engagement (Rahman et al., } \\
\text { 2013; Shi et al., 2016; Walters et al., 2015); human capacity, business } \\
\text { capacity, workforce development (Walters et al., 2015); }\end{array}$ \\
\hline
\end{tabular}

Note: Some factors are policies and practices rather than indicators. They are included in a separated block to that of the indicators. 
Table 2. Impact of Rural Electrification on Socio-economic Development

\begin{tabular}{|c|l|}
\hline Category & \multicolumn{1}{|c|}{ Potential Impacts on Socio-economic Indicators } \\
\hline $\begin{array}{c}\text { Health and } \\
\text { living }\end{array}$ & $\begin{array}{l}\text { Quality of life (Aragaw, 2013; Kanagawa and Nakata, 2008); } \\
\text { health (Javadi et al., 2013); local health and population (Riva et } \\
\text { al., 2018); }\end{array}$ \\
\hline Economic & $\begin{array}{l}\text { [Household] income (Aragaw, 2013; Khandker et al., 2014); } \\
\text { rural markets (Aragaw, 2013); wage (Dinkelman, 2011); } \\
\text { microenterprise development (Dinkelman, 2011); household } \\
\text { debt (van Gevelt, 2014); GDP per capita (Kanagawa and Nakata, } \\
\text { 2008); }\end{array}$ \\
\hline Environment & $\begin{array}{l}\text { Environment for rural development, Indoor air pollution } \\
\text { (Aragaw, 2013), }\end{array}$ \\
\hline Social & $\begin{array}{l}\text { Public services, employment (Aragaw, 2013); female } \\
\text { employment rate (Dinkelman, 2011); Economic and social } \\
\text { inequality (van Gevelt, 2014); migration to urban areas } \\
\text { (urbanisation) (van Gevelt, 2014); education (Javadi et al., 2013; } \\
\text { Kanagawa and Nakata, 2008; Khandker et al., 2014); } \\
\text { poverty (Kanagawa and Nakata, 2008); increased children's } \\
\text { study time (Khandker et al., 2014); labour supply (Khandker et } \\
\text { al., 2014); }\end{array}$ \\
\hline
\end{tabular}

Note: As there is a plethora of studies on this topic, this review is illustrative rather than comprehensive.

Source: Authors' summary from the literature review. 
Table 3. Variable definitions and descriptive statistics

\begin{tabular}{|c|c|c|c|c|c|}
\hline Variables & Definitions & Mean & Maximum & Minimum & $\begin{array}{l}\text { Std. } \\
\text { Dev. }\end{array}$ \\
\hline \multicolumn{6}{|c|}{ Economic indicators } \\
\hline CAB & Current account balance (\% of GDP) & -3.10 & 11.20 & -21.04 & 6.90 \\
\hline DEBT & $\begin{array}{l}\text { External debt stocks (\% of exports of } \\
\text { goods, services, and primary } \\
\text { income) }\end{array}$ & 117.45 & 7 & 20.77 & 49.41 \\
\hline DEBT_01 & External debt stocks (\% of GNI) & 42.61 & 138.15 & 7.98 & 25.96 \\
\hline FDI & $\begin{array}{l}\text { Foreign direct investment, net } \\
\text { inflows (\% of GDP) }\end{array}$ & 4.70 & 17.35 & 0.24 & 3.90 \\
\hline GOVEXP & $\begin{array}{l}\text { General government } \\
\text { consumption } \\
\text { GDP })\end{array}$ & 13.40 & 21.14 & 5.19 & 3.74 \\
\hline INFLATION & $\begin{array}{lll}\text { Inflation, } & \text { consumer } & \text { prices } \\
\text { (annual \%) } & & \end{array}$ & 7.24 & 28.50 & 1.89 & 4.28 \\
\hline MANU & $\begin{array}{l}\text { Manufacturing, value added (\% of } \\
\text { GDP) }\end{array}$ & 14.89 & 31.64 & 3.98 & 5.78 \\
\hline ODA & $\begin{array}{l}\text { Net ODA (official development } \\
\text { assistance) received per capita } \\
\text { (current US\$) }\end{array}$ & 4.49 & 32 & -1.96 & 43.24 \\
\hline PGDP & $\begin{array}{l}\text { GDP per capita, PPP (constant } 2011 \\
\text { international \$), log }\end{array}$ & 8.68 & 9.96 & 6.42 & 0.83 \\
\hline \multicolumn{6}{|l|}{ Energy in } \\
\hline ACE & Access $\mathrm{t}$ & 76.56 & 99.93 & 12.53 & 27.60 \\
\hline EEFFI & $\begin{array}{l}\text { Energy use (kg of oil equivalent) per } \\
\$ 1,000 \text { GDP (constant } 2011 \text { PPP), log }\end{array}$ & 8.62 & 17.14 & 1.82 & 3.83 \\
\hline EIMP & $\begin{array}{l}\text { Energy imports, net (\% of energy } \\
\text { use) }\end{array}$ & -15.36 & 96.32 & -796.20 & 137.66 \\
\hline ELOSS & $\begin{array}{l}\text { Electric power transmission and } \\
\text { distribution losses (\% of output) }\end{array}$ & 17.12 & 60.90 & 5.65 & 11.51 \\
\hline ETIME & Time required to get electricity & & & & 0.54 \\
\hline \multicolumn{6}{|c|}{ Financial indicators } \\
\hline BANK & $\begin{array}{l}\text { Commercial bank branches (per } \\
1,000 \text { adults) }\end{array}$ & 2.09 & 4.05 & -0.58 & 0.95 \\
\hline CREDIT & $\begin{array}{l}\text { Domestic credit to private sector by } \\
\text { banks (\% of GDP) }\end{array}$ & 38.46 & 120.42 & 4.15 & 28.10 \\
\hline INT & terest rate (\%) & & & & 7.55 \\
\hline RINT & Real interest rate (\%) & 6.15 & 32.05 & -6.17 & 6.73 \\
\hline \multicolumn{6}{|c|}{ Natural and infrastructure indicators } \\
\hline ARB & Arable lands (\%) & 15.16 & 59.69 & 0.42 & 14.93 \\
\hline INTERNET & $\begin{array}{l}\text { Individuals using the Internet (\% of } \\
\text { population) }\end{array}$ & 19.59 & 57.15 & 1.07 & 13.03 \\
\hline MOBILE & $\begin{array}{l}\text { Mobile cellular subscriptions (per } \\
100 \text { people) }\end{array}$ & 72.57 & 132.24 & 8.03 & 27.17 \\
\hline POPDEN & $\begin{array}{l}\text { Population density (people per sq. } \\
\text { km of land area), log }\end{array}$ & 140.84 & 1163.07 & 1.74 & 197.61 \\
\hline
\end{tabular}




\begin{tabular}{llrrrrr} 
TELE & $\begin{array}{l}\text { Fixed telephone subscriptions (per } \\
100 \text { people), log }\end{array}$ & 10.25 & 31.41 & 0.04 & 8.62 \\
\hline \multicolumn{2}{l}{ Social indicators } \\
\hline \multirow{2}{*}{ EMPLOYER } & $\begin{array}{l}\text { Employers, total (\% of total } \\
\text { employment) (modelled ILO } \\
\text { estimate) }\end{array}$ & 3.23 & 14.58 & 0.30 & 2.48 \\
SCHOOL & $\begin{array}{l}\text { School enrolment, tertiary (\% gross) } \\
\text { Unemployment, total (\% of total }\end{array}$ & 27.12 & 77.22 & 2.54 & 18.02 \\
UNEMP & $\begin{array}{l}\text { labour force) } \\
\text { Urban population (\% of total) }\end{array}$ & 52.37 & 90.87 & 16.68 & 19.41 \\
\hline
\end{tabular}

Source: World Development Indicators (World Bank, 2018). 
Table 4. BMA results for factors related to electricity access

\begin{tabular}{|c|c|c|c|c|}
\hline Variables & PIP & Pos. Mean & Pos. SD & Con. Positive \\
\hline bank & 0.5889 & 10.5889 & 3.6167 & 1.0000 \\
\hline DGP per capita (pgdp) & 0.4546 & 14.4208 & 5.4596 & 1.0000 \\
\hline school & 0.4222 & 0.5709 & 0.2437 & 1.0000 \\
\hline manufacturing share & 0.4185 & 1.0412 & 0.4173 & 1.0000 \\
\hline internet & 0.4097 & 0.8862 & 0.3111 & 1.0000 \\
\hline tele & 0.4058 & 1.1032 & 0.4492 & 1.0000 \\
\hline FDI & 0.1599 & -1.3305 & 0.6842 & 0.0000 \\
\hline Debt/Export & 0.1406 & 0.1053 & 0.0551 & 0.9990 \\
\hline credit & 0.0892 & 0.1833 & 0.1164 & 0.9680 \\
\hline Debt/GNI & 0.0766 & 0.1755 & 0.1140 & 0.9954 \\
\hline mobile & 0.0763 & 0.2142 & 0.1386 & 1.0000 \\
\hline $\begin{array}{l}\text { Government expenditure } \\
\text { (govexp) }\end{array}$ & 0.0676 & -0.9624 & 0.6420 & 0.0000 \\
\hline Arable land (arb) & 0.0618 & 0.2421 & 0.1701 & 0.9970 \\
\hline Urbanization rate (urban) & 0.0541 & -0.2897 & 0.2316 & 0.0297 \\
\hline inflation & 0.0527 & -0.8525 & 0.6933 & 0.0651 \\
\hline Employer (\%) & 0.0405 & 1.2899 & 1.1225 & 0.9769 \\
\hline Unemployment rate (uemp) & 0.0390 & -0.5640 & 0.4747 & 0.0084 \\
\hline $\begin{array}{l}\text { electricity transmission loss } \\
\text { (eloss) }\end{array}$ & 0.0347 & -0.2308 & 0.2452 & 0.1021 \\
\hline Energy import (\%) (eimp) & 0.0346 & 0.0198 & 0.0208 & 0.9084 \\
\hline Population density (pden) & 0.0284 & 0.0119 & 0.0131 & 0.9687 \\
\hline $\begin{array}{l}\text { Current account balance } \\
\text { (cab) }\end{array}$ & 0.0280 & -0.1722 & 0.5672 & 0.3951 \\
\hline ODA & 0.0278 & -0.0412 & 0.0730 & 0.1931 \\
\hline Lending interest rate (int) & 0.0275 & -0.3495 & 0.4198 & 0.0223 \\
\hline Energy intensity (eeffi) & 0.0228 & 0.4589 & 0.8148 & 0.7967 \\
\hline $\begin{array}{l}\text { Time required to get } \\
\text { electricity (etime) }\end{array}$ & 0.0178 & -1.7390 & 4.8327 & 0.2668 \\
\hline Real interest rate (rint) & 0.0171 & 0.0343 & 0.5205 & 0.3002 \\
\hline
\end{tabular}

Note: Total model space equals $2^{26}$ (67.1 million). The number of models visited was 66,593 . The mean number of regressors was 4.4634 (optimal model). Assuming all variables have equal probability to enter the optimal model, the prior inclusion probability was, therefore, $22.4 \%(1 / 4.4634)$, which can be used as a threshold to select important variables (separated by the dashed line). A uniform model prior was used in the estimation. PIP refers to posterior inclusion probabilities and the variables are ranked according to PIP. Pos. Mean and Pos. SD are conditional posterior mean and standard deviation (on the condition that the variable is included), respectively. The percentage of conditional positive sign is denoted as 'Con. Positive' in the last column. 
Model Inclusion Based on Best 2000 Models

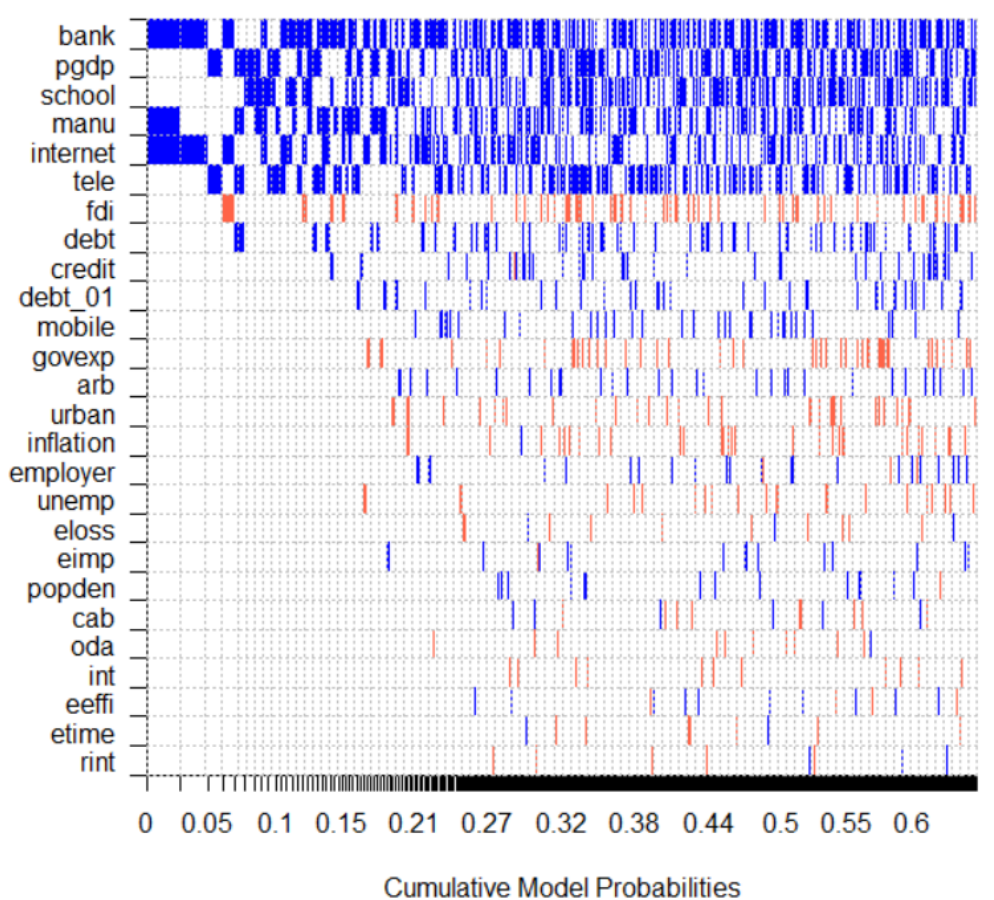

Figure 1. Graphical Illustration of Model Inclusion Probability - Access to Electricity Note: Blue refers to positive relationships, and red is negative relationships. 


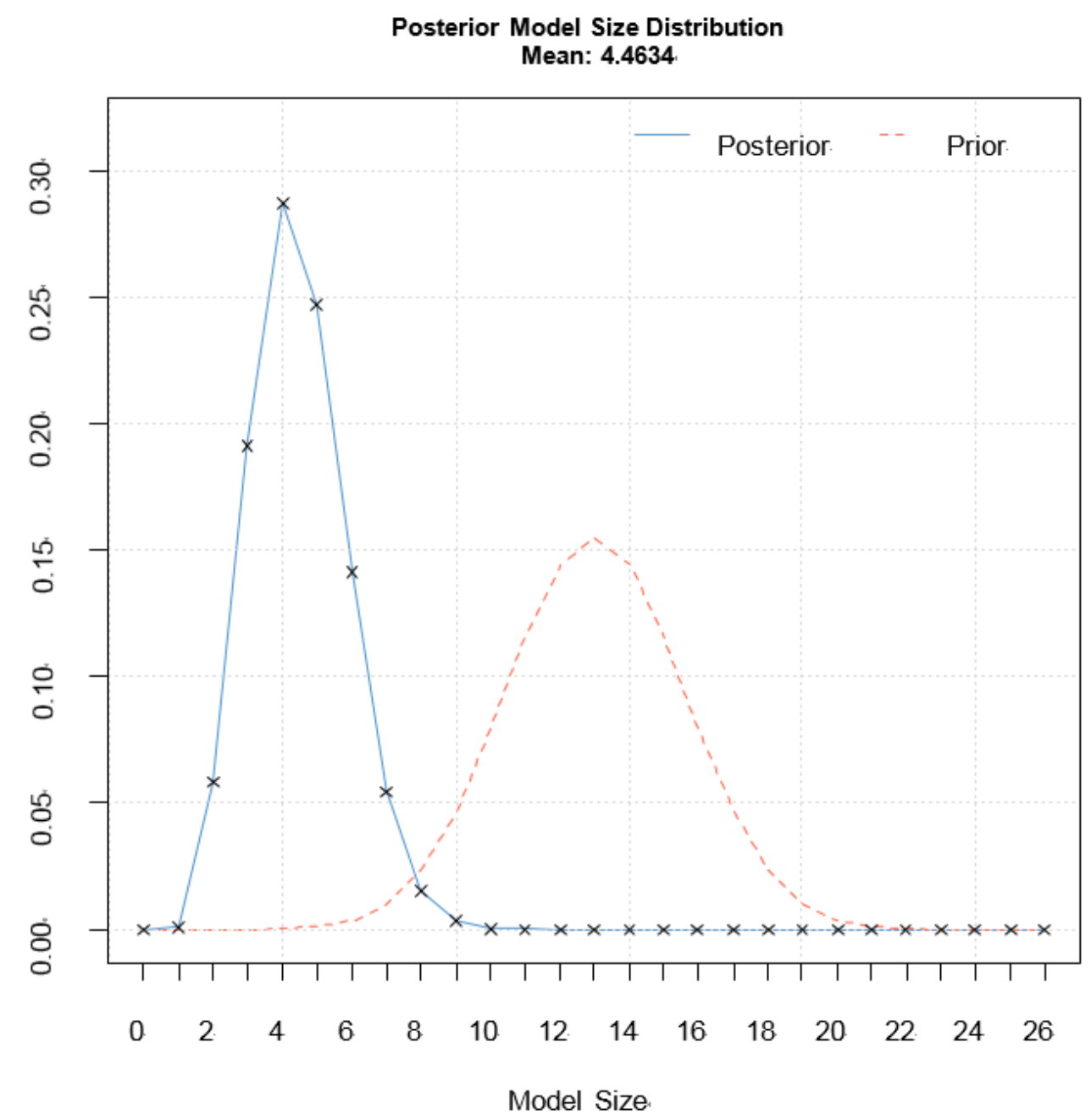

Figure 2. Plot of Model Size 

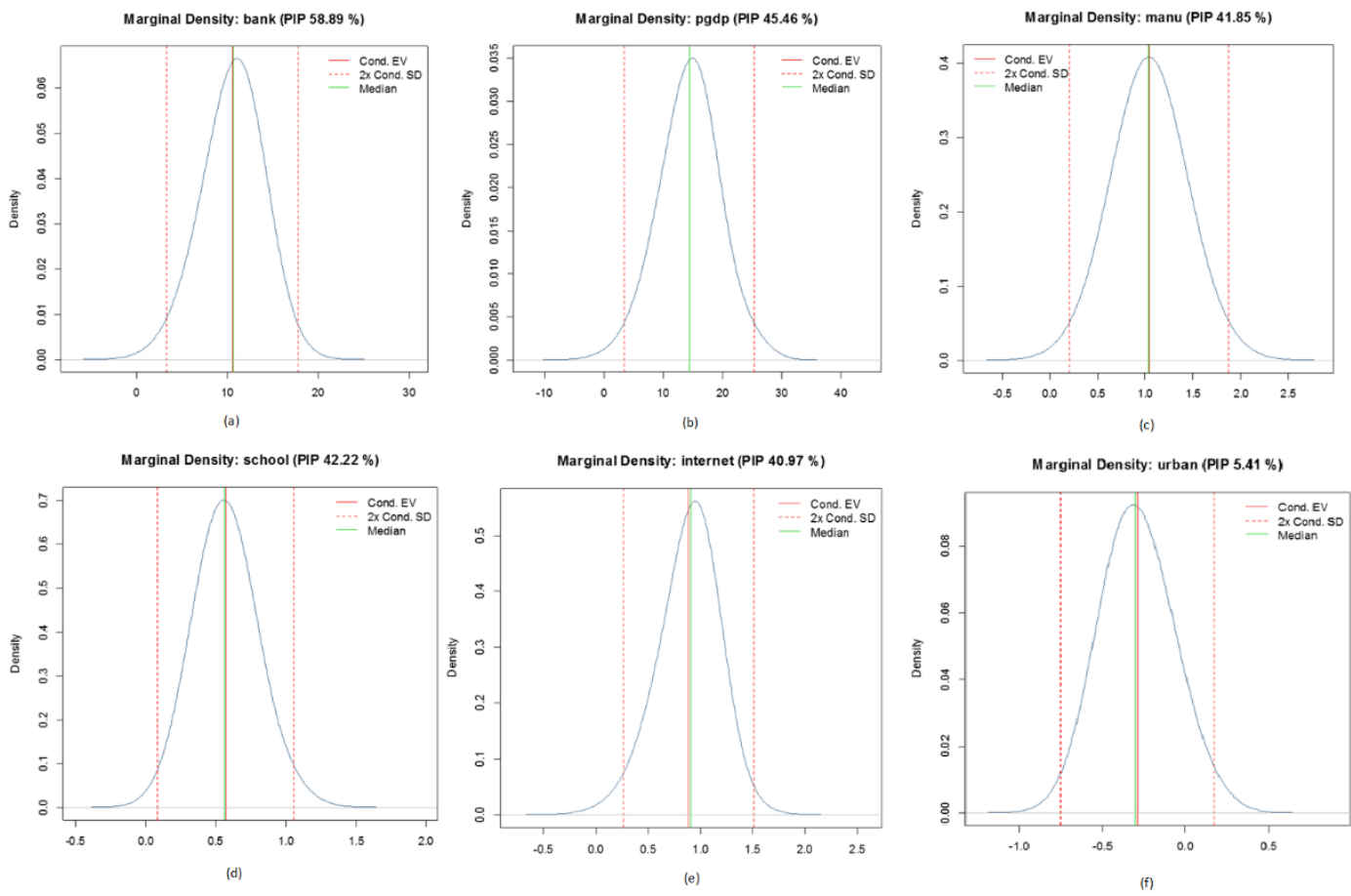

Figure 3. Marginal Densities of the Key Variables 